\title{
Tumor Identifier Sequence Number
}

National Cancer Institute

\section{Source}

National Cancer Institute. Tumor Identifier Sequence Number. NCI Thesaurus. Code C117443.

An identifier that describes the relative position of tumor identifier data within a series. 